\title{
Lipid Rafts in the Maintenance of Synapses, Dendritic Spines, and Surface AMPA Receptor Stability
}

\author{
Heike Hering, Chih-Chun Lin, and Morgan Sheng \\ Picower Center for Learning and Memory, Howard Hughes Medical Institute, and Departments of Brain and Cognitive Sciences and Biology, Massachusetts \\ Institute of Technology, Cambridge, Massachusetts 02139
}

Cholesterol/sphingolipid microdomains (lipid rafts) in the membrane are involved in protein trafficking, formation of signaling complexes, and regulation of actin cytoskeleton. Here, we show that lipid rafts exist abundantly in dendrites of cultured hippocampal neurons, in which they are associated with several postsynaptic proteins including surface AMPA receptors. Depletion of cholesterol/ sphingolipid leads to instability of surface AMPA receptors and gradual loss of synapses (both inhibitory and excitatory) and dendritic spines. The remaining synapses and spines in raft-depleted neurons become greatly enlarged. The importance of lipid rafts for normal synapse density and morphology could explain why cholesterol promotes synapse maturation in retinal ganglion cells (Mauch et al., 2001) and offers a potential link between disordered cholesterol metabolism and the synapse loss seen in neurodegenerative disease.

Key words: cholesterol; sphingolipid; mevastatin; fumonisin $\mathrm{B}_{1}$; endocytosis; cytoskeleton

\section{Introduction}

"Lipid rafts," composed primarily of cholesterol and sphingolipids, form dynamic microdomains in cellular membranes. These microdomains are dispersed in the more fluid liquid-disordered phase of glycerolipids. Proteins specifically incorporated into lipid rafts often carry lipid modifications such as glycosylphosphatidylinositol (GPI)-anchors, or dual palmitoylation or myristoylation, or directly bind cholesterol (Simons and Ikonen, 1997). Transmembrane proteins can also partition into lipid rafts, but the mechanism of their raft association is unclear. Differential affinity for rafts leads to compartmentalization of specific proteins in the plane of the membrane.

In particular, signaling proteins with affinity for rafts become concentrated in these microdomains, thus facilitating formation of protein complexes and activation of specific signaling pathways. Several signal transduction pathways are organized in the context of lipid rafts (Simons and Toomre, 2000).

Rafts are also involved in membrane traffic. The inclusion of certain proteins into rafts is important for their targeted delivery to specialized cellular sites (Brown and Rose, 1992). Lipid rafts also play a role in the endocytosis of proteins from the cell surface and in intracellular sorting (Nichols and Lippincott-Schwartz, 2001).

Cholesterol/sphingolipid rafts also interact with the submembraneous actin cytoskeleton (Caroni, 2001; Foger et al., 2001; Itoh et al., 2002). Consistent with a role in regulation of actin cytoskeleton, lipid rafts have been implicated in the mechanisms of cell polarity, cell migration, and motility of membrane protrusions such as microvilli and lamellipodia (Meivar-Levy et al.,

\footnotetext{
Received Aug. 28, 2002; revised Dec. 23, 2002; accepted Feb. 6, 2003

M.S. is Associate Investigator at the Howard Hughes Medical Institute. We thank Valentin Piëch for excellent technical assistance.

Correspondence should be addressed to Morgan Sheng, Picower Center for Learning and Memory, Howard Hughes Medical Institute, Massachusetts Institute of Technology, 77 Massachusetts Avenue (E18-215), Cambridge, MA 02139. E-mail:msheng@mit.edu.

Copyright $\odot 2003$ Society for Neuroscience $\quad$ 0270-6474/03/233262-10\$15.00/0
}

1997; Manes et al., 1999; Gomez-Mouton et al., 2001). In summary, cholesterol-rich microdomains are involved in localized signaling at the membrane, trafficking of membranes and proteins, and regulation of cortical actin.

Neurons are polarized cells whose function depends on the segregation of proteins to specific microdomains of the membrane. In most principal neurons, motile actin-rich structures (spines) protrude from dendrites, with each spine normally accommodating a single synapse (for review, see Hering and Sheng, 2001). Spine morphogenesis is critical for compartmentalized synaptic signaling by principal neurons. A multiproteinsignaling complex is assembled at the postsynaptic membrane of dendritic spines, some components of which have the lipid modifications typical for raft-associated proteins [e.g., postsynaptic density (PSD)-95 and glutamate receptor (GluR)-interacting protein (GRIP)] (Topinka and Bredt, 1998; Yamazaki et al., 2001). This complex is connected to the subsynaptic actin-based cytoskeleton, the dynamic rearrangements of which underlie the motility of spines. In addition, regulated trafficking of membrane proteins occurs in the postsynaptic compartment, which affects the strength of synaptic transmission via the exocytosis and endocytosis of AMPA receptors (for review, see Carroll et al., 2001; Sheng and Lee, 2001). Thus, several postsynaptic processes important for synaptic function and morphology could depend on cholesterol-rich lipid rafts, but this area has been little explored. Intriguingly, a recent study identified cholesterol as a glia-derived factor important for synapse formation by neurons (Mauch et al., 2001).

Here, we present evidence that lipid rafts exist in the dendrites of neurons, where they are associated with a set of postsynaptic proteins. Disruption of lipid rafts leads to depletion of excitatory and inhibitory synapses, loss of dendritic spines, and instability of surface AMPA receptors.

\section{Materials and Methods}

Antibodies. The following antibodies have been described previously: rabbit antisera Shank 56/e (Naisbitt et al., 1999), synapse-associated 
protein-97 (SAP97) (Kim and Sheng, 1996), GRIP2 (1757/4) (Wyszynski et al., 1998), guinea pig PSD-95 antiserum used for immunocytochemistry (Kim et al., 1995); and mouse monoclonal PSD-95 antibody K28/43 used for immunoblots (gift from J. Trimmer, State University of New York, Stony Brook, NY). The following antibodies were purchased from commercial sources: $\mathrm{GABA}_{\mathrm{A}}$ receptor (clone MAB341), GluR1 for immunoblots, and GluR2/3 (Chemicon, Temecula, CA); MAP2 (clone HM-2), syntaxin (clone HPC-1), and $\beta$-tubulin (clone TUB 2.1) (Sigma, St. Louis, MO); NMDA receptor-1 (clone 54.1) (PharMingen, San Diego, CA); Thy-1 (clone MRC OX-7) (Serotec, Oxford, UK); transferrin receptor (clone H68.4) (Zymed, San Francisco, CA); caveolin (N-20) (Santa Cruz Biotechnology, Santa Cruz, CA); GluR1 for immunocytochemistry (Ab-1) (Oncogene Sciences, Cambridge, MA); and bassoon (Stress Gen, Victoria, Canada).

Preparation of detergent-resistant membranes and assays for cholesterol and sphingolipid. Adult rat brain was homogenized in a Glas-Col homogenizer in ice-cold homogenization buffer (HB; $10 \mathrm{~mm}$ Tris, pH 7.4, $5 \mathrm{~mm}$ EDTA, $320 \mathrm{~mm}$ sucrose, $1 \mu \mathrm{g} / \mathrm{ml}$ pepstatin, $1 \mu \mathrm{g} / \mathrm{ml}$ aprotinin, $250 \mu \mathrm{M}$ benzamidine, $1 \mu \mathrm{g} / \mathrm{ml}$ leupeptin, $2 \mathrm{~mm}$ PMSF, $2 \mathrm{~mm}$ sodium vanadate, and $1 \mathrm{~mm}$ sodium fluoride). After centrifugation at $800 \times g$ for $10 \mathrm{~min}$, the ensuing supernatant was spun at $9200 \times g$ for $15 \mathrm{~min}$. The pellet (P2) was resuspended in $\mathrm{HB}$ and spun at $10,200 \times \mathrm{g}$ for $15 \mathrm{~min}$. The pellet $\left(\mathrm{P} 2^{\prime}\right)$ was resuspended in TNE buffer (50 mM Tris, pH 7.4, $150 \mathrm{~mm} \mathrm{NaCl}$, and 5 mM EDTA) and sonicated (Branson Sonifier 450, setting 4; Branson, Danbury, CT) for $5 \mathrm{sec}$. Resuspended P2' was extracted in cold TNXE buffer (TNE containing Triton X-100 at a final concentration of $0.5 \%$ ) with rotation for $20 \mathrm{~min}$ at $4^{\circ} \mathrm{C}$, followed by $10 \mathrm{~min}$ of incubation on ice. For the first gradient, the extract was adjusted to $30 \%$ Nycodenz (Nycomed Pharma, Roskilde, Denmark) in 0.5\% TNXE, split into two Quickseal tubes $(16 \times 76 \mathrm{~mm}$; Beckman Instruments, Fullerton, CA), and overlaid with $9 \mathrm{ml}$ of $25 \%$ and $1 \mathrm{ml}$ of $5 \%$ Nycodenz, all in $0.5 \%$ TNXE. After centrifugation for $3.5 \mathrm{hr}$ (50,000 rpm; Ti 70.1 rotor; Beckman Instruments), $131 \mathrm{ml}$ fractions were collected from the top. For the second gradient, the $\mathrm{P} 2$ ' detergent extract was adjusted to $30 \%$ Nycodenz in $0.5 \%$ TNXE, split into two Optiseal tubes $(16 \times 60 \mathrm{~mm}$; Beckman Instruments), and overlaid with $3 \mathrm{ml}$ of $25 \%, 3.5 \mathrm{ml}$ of $15 \%$, and $0.5 \mathrm{ml}$ of $5 \%$ Nycodenz, all in $0.5 \%$ TNXE. The tubes were centrifuged as described above and nine fractions of $1 \mathrm{ml}$ were collected from the top. Equal volumes of the fractions were separated by SDS-PAGE and analyzed by immunoblotting.

For detection of ganglioside $\mathrm{G}_{\mathrm{Ml}}, 1 \mu \mathrm{l}$ of each fraction was applied to a nitrocellulose membrane and probed with horseradish peroxidasecoupled cholera-toxin subunit B (10 ng/ml; Sigma). To measure cholesterol, $5 \mu \mathrm{l}$ of each fraction was analyzed with the Amplex Red cholesterol assay kit (Molecular Probes, Eugene, OR) according to the manufacturer's instruction. Protein concentration was determined using the $\mathrm{D}_{\mathrm{C}}$ protein assay (Bio-Rad, Hercules, CA).

Neuronal culture, raft depletion, and filipin labeling. Hippocampal primary cultures were prepared from embryonic day 18 (E18)-E19 rat embryos as described previously (Sala et al., 2000). Medium-density cultures $\left(\sim 150\right.$ cells $\mathrm{mm}^{-2}$ ) were plated on coverslips coated with polyD-lysine $(30 \mu \mathrm{g} / \mathrm{ml})$ and laminin $(2.5 \mu \mathrm{g} / \mathrm{ml})$. Cultures were grown in Neurobasal medium (Invitrogen, Carlsbad, CA) and supplemented with B27 (Invitrogen), $0.5 \mathrm{~mm}$ glutamine, and $12.5 \mu \mathrm{M}$ glutamate. For sphingolipid and cholesterol depletion experiments, medium-density cultures at 10-14 d in vitro (DIV) were treated with $10 \mu \mathrm{M}$ fumonisin $\mathrm{B}_{1}$ (Sigma), $4 \mu \mathrm{M}$ mevastatin (Calbiochem, San Diego, CA), and $250 \mu \mathrm{M}$ mevalonate (Sigma). The drug application was repeated $4 \mathrm{~d}$ after the first treatment.

Labeling of plasma membrane cholesterol by filipin (Sigma) was performed as follows: neurons were fixed for $5 \mathrm{~min}$ in $4 \%$ formaldehyde and $4 \%$ sucrose in PBS, pH 7.4. Autofluorescence of neurons was quenched by incubation of the cells in $50 \mathrm{mM} \mathrm{NH}_{4} \mathrm{Cl}$ for $10 \mathrm{~min}$. Neurons were then pretreated with $0.005 \%$ digitonin for $10 \mathrm{~min}$ followed by incubation in $100 \mu \mathrm{g} / \mathrm{ml}$ filipin for $10 \mathrm{~min}$.

DiIC $_{18}$ /FAST-DiO labeling of neurons and membrane or cholesterol extraction. Neurons at $\sim 21$ DIV were fixed in $4 \%$ formaldehyde and $4 \%$ sucrose in PBS, pH 7.4, for 3 min, washed in PBS, and incubated in a DiIC $_{18} /$ FAST-DiO mixture $(0.4 \mu \mathrm{g} / \mathrm{ml}$ each in PBS; Molecular Probes) for $1 \mathrm{~min}$. After incubation in PBS for $48 \mathrm{hr}$ at $4^{\circ} \mathrm{C}$ to allow diffusion of the dyes, the cells were extracted with $0.5 \%$ Triton X-100 in $20 \mathrm{~mm}$ phosphate buffer, $\mathrm{pH} 7.4$, for $10 \mathrm{~min}$ at $4^{\circ} \mathrm{C}$, and mounted on glass slides with SlowFade Light reagent (Molecular Probes).

Cholesterol was acutely extracted from the cell membrane as described previously (Ledesma et al., 1998), except that neurons were incubated for $20 \mathrm{~min}$ in the presence of $5 \mathrm{~mm}$ methyl- $\beta$-cyclodextrin ( $\mathrm{m} \beta \mathrm{CD}$; Sigma). The cells were fixed in formaldehyde, labeled with DiI, and processed as described above.

Transfection, immunocytochemistry, and FM 1-43 staining. Neurons were transfected at $\sim 7$ DIV using the calcium phosphate method (Sala et al., 2001). For immunostaining of endogenous PSD-95, NMDA receptor, Shank, and bassoon, the cells were fixed in methanol at $-20^{\circ} \mathrm{C}$ for 10 min. For $\mathrm{GABA}_{\mathrm{A}}$ receptor staining, phalloidin labeling, or the detection of transfected PSD-95, cells were fixed in $4 \%$ formaldehyde or $4 \%$ sucrose in PBS, pH7.4, for $10 \mathrm{~min}$ at room temperature. Immunostaining was performed as described previously (Sala et al., 2000), except that Alexa 488- and Alexa 543-conjugated secondary antibodies (Molecular Probes) were used.

FM 1-43 staining was performed by incubating neurons for $1 \mathrm{~min}$ in 6 $\mu \mathrm{M}$ FM 1-43 (Molecular Probes) in high potassium buffer (in mм: 90 $\mathrm{KCl}, 55 \mathrm{NaCl}, 10$ HEPES, pH 7.4, 10 glucose, $2.6 \mathrm{CaCl}_{2}$, and $1.3 \mathrm{MgCl}_{2}$ ), followed by two washes in Tyrode solution $(145 \mathrm{~mm} \mathrm{NaCl}, 3 \mathrm{~mm} \mathrm{KCl}, 10$ mM HEPES, pH 7.4, $10 \mathrm{~mm}$ glucose, $5 \mu \mathrm{m}$ glycine, $2.6 \mathrm{mM} \mathrm{CaCl}_{2}$, and 1.3 $\mathrm{mm} \mathrm{MgCl}_{2}$ ) in the presence of $1 \mu \mathrm{M}$ tetrodotoxin (TTX).

Surface labeling of AMPA receptors, detergent extraction, and internalization assays. Surface AMPA receptors were labeled by incubating live neurons with GluR1 antibody $(10 \mu \mathrm{g} / \mathrm{ml})$ at $37^{\circ} \mathrm{C}$ for $15 \mathrm{~min}$. After washing in culture medium, the neurons were extracted with $0.5 \%$ Triton $\mathrm{X}-100$ in $20 \mathrm{~mm}$ phosphate buffer, $\mathrm{pH} 7.4$, at $4^{\circ} \mathrm{C}$ or $37^{\circ} \mathrm{C}$ for $10 \mathrm{~min}$, or pretreated with $0.5 \%$ saponin in $20 \mathrm{~mm}$ phosphate buffer, $\mathrm{pH} 7.4$, at $4^{\circ} \mathrm{C}$ for $10 \mathrm{~min}$, followed by extraction in $0.5 \%$ Triton X-100 at $4^{\circ} \mathrm{C}$. After fixation in $4 \%$ formaldehyde or $4 \%$ sucrose in PBS, pH 7.4, for 10 min the primary antibodies were detected by Alexa 488 secondary antibodies.

The antibody-feeding assay for the internalization of AMPA receptors was performed essentially as described previously (Lin et al., 2000), except that neurons were incubated with GluR1 antibody for $15 \mathrm{~min}$ at $37^{\circ} \mathrm{C}$.

Quantitation. For filipin staining, images were acquired with the $4^{\prime}, 6^{\prime}$ diamidino-2-phenylindole filter setting on a Nikon (Tokyo, Japan) Eclipse 600 microscope and a cooled CCD camera. Filipin fluorescence intensity was measured in areas of identical size (three areas per image, 10 images per condition). All other images were acquired using a LSM510 or Pascal confocal microscope (Zeiss, Jena, Germany). All confocal images were $z$-series projections of $\sim 7-12$ images taken at $0.45-0.6 \mu \mathrm{m}$ depth intervals. Images used for quantitation were taken with identical microscope settings and analyzed using MetaMorph software (Universal Imaging Corporation, West Chester, PA). For quantitation of PSD-95 cluster area, images were under threshold conditions to subtract background labeling and the area of the clusters was measured. Approximately 7000 clusters were measured for each condition (from five microscope fields). For quantitation of synapse density, images were under threshold conditions as the quantitation of cluster area and the number of PSD-95 clusters per dendritic length were counted. For quantitation of spine size, $\sim 4000$ spines were measured for each culture condition (from 20 to 30 neurons). Unbranched dendritic protrusions with a defined head were defined as spines. The length of spines from the base of the neck to the furthest point on the spine head and the maximal width of the spine head perpendicular to the long axis of the spine neck were measured. For each condition, individual spine measurements were first grouped and averaged per neuron; means from multiple neurons were then averaged to obtain a population mean. For the quantitation of GluR1 surface-staining intensity, three images for each condition were under threshold conditions and the total intensity of the clusters was measured. Quantitation of AMPA receptor internalization was as described previously (Lin et al., 2000).

\section{Results}

A subset of postsynaptic proteins associates with lipid rafts

We isolated detergent-resistant membranes (DRM) from a crude membrane fraction of adult rat brain on the basis of their insolubility in Triton X-100 at $4^{\circ} \mathrm{C}$ (Brown and Rose, 1992) and their 
ability to float in density gradients. Lipid raft-containing fractions were tracked by the enrichment of cholesterol and sphingolipids as well as the GPI-anchored cellsurface protein Thy-1 and the cholesterolbinding protein caveolin (Fig. 1A). Cholesterol and the sphingolipid ganglioside $G_{M 1}$ were greatly enriched in fraction 2 of Nycodenz gradients. Low levels of the two lipids were also detected in the three bottom fractions. Similar to cholesterol and sphingolipids, Thy-1 showed highest enrichment in fraction 2. Caveolin also peaked in the light fractions (fractions 2 and 3), with an additional peak at higher density (fraction 9). In contrast, the transferrin receptor, which is excluded from lipid rafts, amassed at the bottom of the gradient (fractions 10-13), where the majority of total protein was found. We tested several synaptic proteins for association with lipid rafts. GRIP, a multi-PSD95/Disks large/zona occludens-1 scaffold protein that interacts with AMPA receptor subunits GluR2/3, has been shown to associate with lipid rafts in rat brain (Bruckner et al., 1999). We found that although most of GRIP was at the bottom of the gradient, a significant portion of GRIP floated in the top fractions (fractions 2 and 3), along with Thy-1 and caveolin (Fig. 1A). In keeping with the association of GRIP and AMPA receptors in rat brain (Wyszynski et al., 1999), AMPA receptor subunits GluR2/3 and GluR1 showed a prominent peak in the "floating" fractions similar to GRIP. However, SAP97 (a protein that binds to GluR1) was absent from fractions 2 and 3.

PSD-95, a relative of SAP97 and a major protein of the postsynaptic density, was abundantly present in the lipid raft fractions (fractions 1-3) (Fig. 1A), although the majority localized at the bottom of the gradient (fractions 9-13). In keeping with the interaction of NMDA receptors and PSD-95 in the brain, NMDA receptor subunit NR1 cofractionated with PSD-95, showing a strong peak in the low-density fractions 1-3 (Fig. 1A). Syntaxin was not enriched in these fractions, indicating that the floating fractions were not contaminated with synaptosomes.

Lipid rafts are not homogeneous in their composition and properties; rather, different subtypes exist that differ in their resistance to detergent extraction and/or density (Madore et al., 1999; Roper et al., 2000; Gomez-Mouton et al., 2001). Using the same detergent-extraction conditions as before $(0.5 \%$ Triton $\mathrm{X}-100$ at $4^{\circ} \mathrm{C}$ ), but changing the gradient to increase resolution in the lighter density range, we were able to distinguish different fractionation patterns for the investigated proteins (Fig. $1 B$ ). The raft-marker proteins Thy-1 and caveolin now behaved distinctly, with Thy-1 peaking at a lower density (fractions 2-5) than caveolin (fractions 4-7), suggesting that Thy-1-containing rafts in the brain differ from "caveolin-type" rafts. The "negative controls," transferrin receptor and syntaxin, remained in the bottom fractions as expected. GRIP was concentrated in the bottom fractions but extended throughout the gradient, showing considerable en-

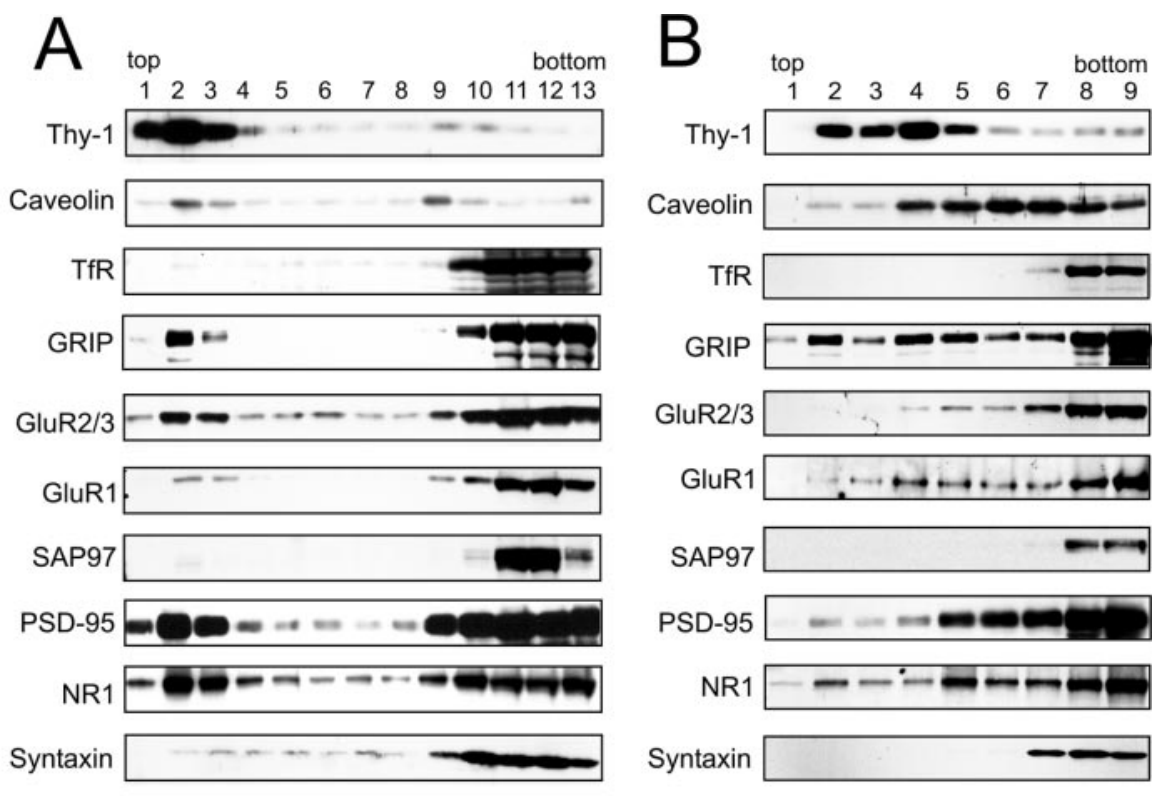

Figure 1. Postsynaptic proteins associated with lipid rafts. A, Adult rat brain membranes were extracted in $0.5 \%$ Triton X-100 and separated on a density gradient formed from 30, 25, and 5\% Nycodenz. Thirteen fractions (from top to bottom of gradient) toxin subunit B), cholesterol, and total protein (see Materials and Methods). B, The same Triton X-100 extract used in $A$ was separated on a density gradient formed from $30,25,15$, and $5 \%$ of Nycodenz. Nine fractions were collected from the top and immunoblotted for the indicated proteins. TfR, Transferrin receptor; Chol. tox., cholera-toxin subunit B.

richment in fractions 2-5 where it overlapped with Thy-1. GluR1 and GluR2/3 were also concentrated in the high-density fractions, but extended into lower density fractions $(4-7)$ that were more similar to caveolin than Thy-1. PSD-95 and NR1 showed a similar fractionation pattern: the highest level was found in the bottom fractions, but substantial amounts were present at lower densities, particularly fractions 5-7 and, to a lesser extent, fractions 2-4. Thus, PSD-95 and NR1 under these conditions fractionated more similarly to caveolin than Thy-1. SAP97 appeared only in the bottom fractions. Together, our data suggest that several postsynaptic proteins (GRIP, AMPA receptors, PSD-95, and NMDA receptors) are partially associated with Triton X-100 resistant membranes (rafts) in the rat brain. However, these rafts have distinct properties from those associated with Thy-1, a GPIlinked glycoprotein concentrated in axons (Dotti et al., 1991).

\section{Detergent-resistant membranes in neurons have lipid raft-like properties}

By analogy to epithelial cells, it has been suggested that lipid rafts in neurons are primarily confined to the axonal compartment (Ledesma et al., 1998). However, our fractionation studies suggest that some postsynaptic proteins are associated with rafts (Fig. 1). To visualize directly the presence of DRM in the somatodendritic compartment, we labeled cultured hippocampal neurons with the fluorescent lipid dyes DiIC $_{18}$ (red) and FAST-DiO 


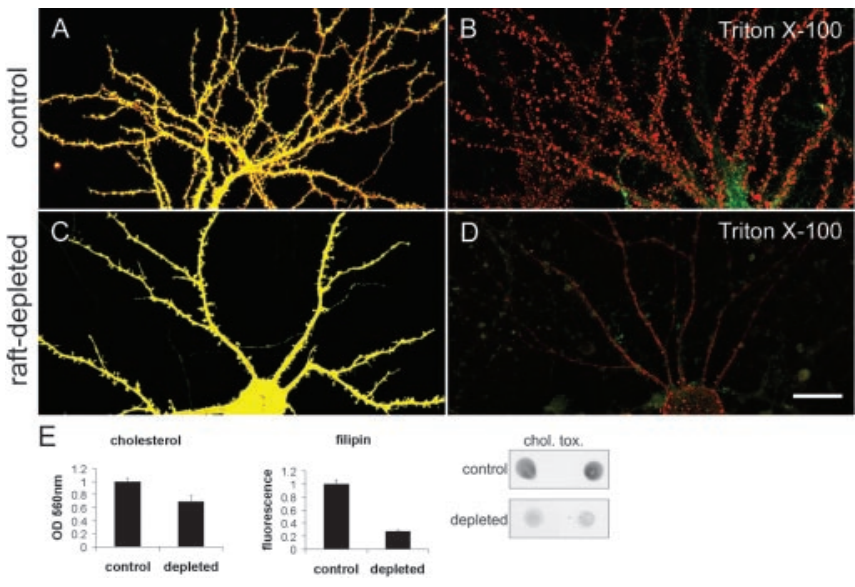

Figure 2. Detergent-resistant membranes in dendrites of cultured neurons. A, Hippocampal neuron at 21 DIV double-labeled with DilC ${ }_{18}$ (red) and FAST-Di0 (green). B, DilC ${ }_{18} /$ FAST-DiOlabeled hippocampal neuron after extraction with $0.5 \%$ Triton $X-100$ at $4^{\circ} \mathrm{C}$. C, Hippocampal neuron treated with mevastatin, fumonisin $\mathrm{B}_{1}$, and mevalonate for $5 \mathrm{~d}$ labeled with Dil $\mathrm{C}_{18}$ and FAST-Di0. D, DilC 18 /FAST-Di0-labeled hippocampal neuron treated as in C, after extraction with $0.5 \%$ Triton X-100 at $4^{\circ}$ C. Scale bar, $20 \mu \mathrm{m} . E$, Cholesterol and sphingolipid levels in control and raft-depleted cultures. Cholesterol levels in raft-depleted cultures were decreased $\sim 31 \%(p<$ $0.05)$ on the basis of an enzymatic cholesterol-detection assay, or $\sim 72 \%(p<0.001)$ on the basis of binding of fluorescent filipin. Ganglioside $G_{M 1}$ levels were reduced on the basis of cholera-toxin subunit $B$ (chol. tox.) binding in a dot-blot assay.

(green). DiIC ${ }_{18}$ has been used as a marker of DRM because of its ability to partition into cholesterol/sphingolipid-rich membranes, whereas FAST-DiO, with its unsaturated acyl chains, is relatively excluded from rafts (Mukherjee et al., 1999; Seveau et al., 2001). Double-labeling of neurons with DiIC $_{18}$ and FAST$\mathrm{DiO}$ resulted in an apparently diffuse labeling by both dyes of the neuronal plasma membrane, which therefore appeared yellow (Fig. 2A). This is consistent with a widespread intermingling of raft and nonraft microdomains. Extraction of stained neurons with $0.5 \%$ Triton $\mathrm{X}-100$ at $4^{\circ} \mathrm{C}$ selectively extracted FAST-DiO, leaving behind Triton X-100-resistant membrane patches containing red $\mathrm{DiIC}_{18}$ fluorescence (Fig. $2 \mathrm{~B}$ ). The detergent-resistant membrane patches were distributed along the dendrites and on the soma of the cell, indicating that the somatodendritic compartment of hippocampal neurons contains membranes with lipid raft-like properties.

To confirm that the DRMs seen in the above experiment (Fig. $2 B$ ) are caused by the presence of cholesterol/sphingolipid rafts, we treated hippocampal neurons for a week with fumonisin $B_{1}$ and mevastatin (inhibitors of sphingolipid and cholesterol synthesis). The cholesterol level was significantly lowered in fumonisin $\mathrm{B}_{1}$ - and mevastatin-treated cultures, as revealed by an enzymatic assay for cholesterol or by labeling with filipin, a cholesterol-binding fluorescent dye (Fig. 2 E). Sphingolipid levels were also reduced, relative to control cultures, on the basis of dot-blot analysis with cholera-toxin subunit B, which binds ganglioside GM1 (Fig. 2E). In fumonisin $B_{1}$ - and mevastatin-treated ("raft-depleted") neurons, staining by DiIC ${ }_{18}$ and FAST-DiO was diffuse and similar to untreated control neurons (Fig. 2C). However, after extraction with cold Triton X-100, the treated neurons lost not only the FAST-DiO (green) staining but also the vast majority of the $\mathrm{DiIC}_{18}$ labeling (Fig. $2 \mathrm{D}$, red). Together, these data indicate that the dendritic compartment of neurons contains abundant DRM domains that are enriched in cholesterol and sphingolipids.
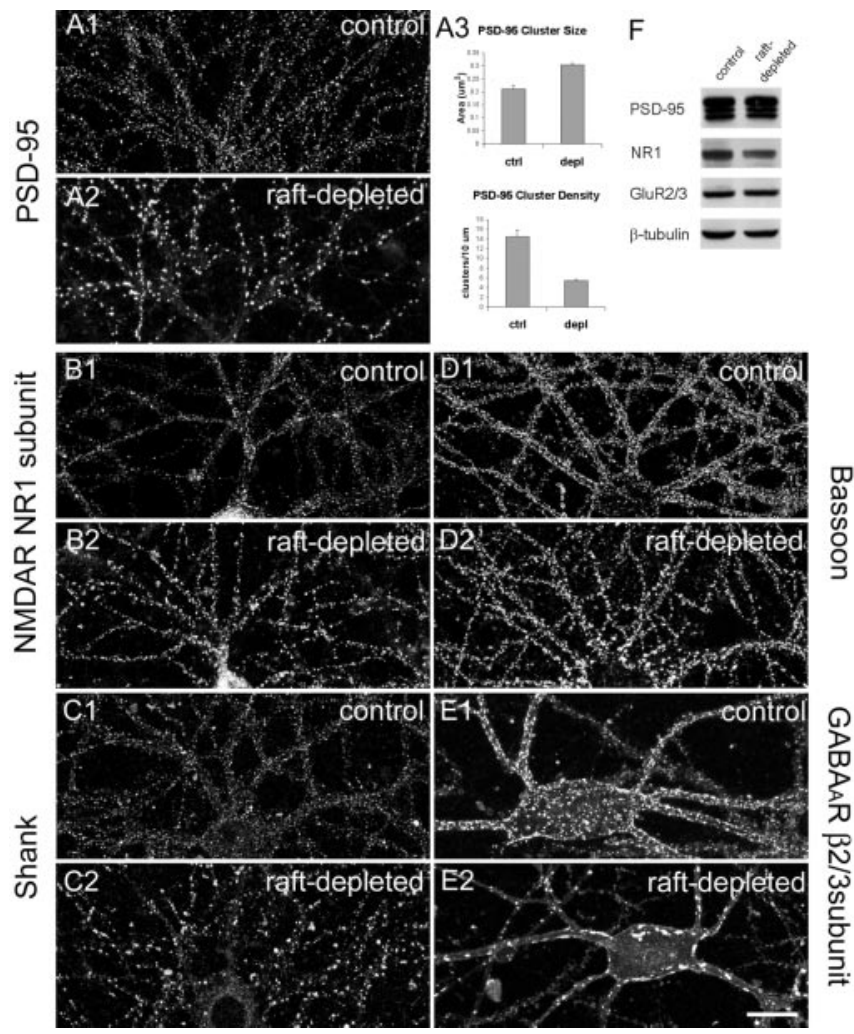

Figure 3. Lipid-raft depletion reduces the number but increases the size of synapses. All images were taken from hippocampal neurons at 21 DIV. A1, Control hippocampal neurons stained for PSD-95. A2, Hippocampal neurons treated for $7 \mathrm{~d}$ with mevastatin, fumonisin $\mathrm{B}_{1}$, and mevalonate (raft-depleted) and stained for PSD-95. A3, Quantitation of PSD-95 cluster size and density in control (ctrl) and raft-depleted (depl) neurons. Histograms show mean \pm SEM; $n=5$ microscope fields for each condition. Differences in cluster size $(p=0.0036)$ and density $(p=0.0024)$ are significant (Student's $t$ test). $B-E$, Control and raft-depleted neurons stained for NR1 subunit of NMDA receptor (NMDAR; B1, B2), Shank (C1, C2), bassoon (D1,D2), and $\beta 2 / 3$ subunit of $G A B A_{A}$ receptor $\left(G A B A_{A} R ; E 1, E 2\right)$. Scale bar, $20 \mu \mathrm{m}$. $F$, Total cell lysate of control and raft-depleted hippocampal cultures immunoblotted for the indicated proteins. Anti-tubulin immunoblotting confirmed equal loading of protein.

\section{Raft depletion reduces the density and increases the size of synapses}

Because postsynaptic proteins such as PSD-95, GRIP, and their glutamate receptor partners are associated, at least in part, with lipid rafts (Fig. 1), we investigated whether such microdomains are involved in the formation and maintenance of synapses. To deplete lipid rafts, we treated hippocampal cultures at $\sim 12-14$ DIV with inhibitors of sphingolipid and cholesterol synthesis for 5-7 d, spanning a period of active synapse formation and maturation in culture. In untreated neurons, the postsynaptic marker PSD-95 appeared as numerous small puncta along dendrites (Fig. $3 A 1)$. In raft-depleted neurons, the density of PSD-95 puncta was greatly reduced (to $\sim 37 \%$ of control; $p<0.05$ ) (Fig. 3A2,A3). The remaining PSD-95 clusters showed $\sim 1.5$-fold increase in size (Fig. 3A2,A3, pixel area). Similarly, NMDA receptor subunit NR1 was concentrated in many small dendritic puncta in control neurons (Fig. 3B1), but in neurons treated with fumonisin $B_{1}$ and mevastatin, NR1 clusters were fewer in number and larger in size (Fig. 3B2). Raft depletion also led to decreased number and increased size of clusters of Shank (Fig. 3C), another major scaffold protein of the PSD (Naisbitt et al., 1999; Sala et al., 2001). For the presynaptic active-zone protein bassoon, we observed an effect of lipid raft depletion similar to that seen for the postsynaptic proteins PSD-95, NR1, and Shank. Bassoon clusters decreased in 
density but increased in apparent size (Fig. 3D), indicating that a corresponding change was occurring on the presynaptic side. Because multiple synaptic markers are similarly affected, we conclude that cholesterol/sphingolipid depletion causes a decrease in overall synapse density, concomitant with an increase in size of the remaining synapses.

To test whether the effect of raft depletion on synaptic clusters was reversible, we treated cultured hippocampal neurons at 12 DIV with the raft-depleting drugs, after which we let the neuron cultures recover in the absence of the drugs. We monitored the synaptic changes by determining the cluster size of PSD-95, a particularly robust effect that was relatively easy to quantify. At 18 DIV, after $6 \mathrm{~d}$ of drug treatment, PSD-95 cluster size had increased relative to control neurons. However, PSD-95 cluster size in neurons treated for $6 \mathrm{~d}$ with drugs and recovered for $5 \mathrm{~d}$ without drugs was not statistically different from same-age cells that were never exposed to the drug $(p=0.346$; Student's $t$ test). These results suggest that the effect of cholesterol/sphingolipid drugs on synapses is reversible.

Inhibitory $\mathrm{GABA}_{\mathrm{A}}$ receptors also showed a striking change in their distribution under raftdepleting conditions, and this change was particularly prominent on interneurons (Fig. $3 E$ ). The $\beta 2 / 3$ subunits of the $\mathrm{GABA}_{\mathrm{A}}$ receptors in control neurons were localized to numerous small clusters on the soma and along the dendrites (Fig. 3E1), but in treated neurons the $\mathrm{GABA}_{\mathrm{A}}$ receptors accumulated in a few very large aggregates (Fig. 3E2). Immunostaining of $\mathrm{GABA}_{\mathrm{A}}$ receptors in nonpermeabilized neurons confirmed that these aggregates were located in the plasma membrane (data not shown). Thus depletion of cholesterol and sphingolipids had a similar morphological effect on both excitatory synapses and inhibitory synapses. Fumonisin $B_{1}$ and mevastatin did not change the total level of PSD-95, NMDA receptors and AMPA receptors on Western blots (Fig. $3 F$ ), suggesting that the loss of synapse number is not attributable to altered expression of these synaptic proteins. Together, these data indicate that cholesterol/sphingolipid rafts are important for the maintenance and/or formation of synapses in hippocampal neurons.

\section{Raft depletion causes loss of spines and increased spine size} Because lipid rafts are implicated in actin-cytoskeleton regulation, we wondered whether sphingolipid/cholesterol rafts are important for dendritic spine morphogenesis. To facilitate visualization of dendritic spines on individual neurons within a medium-density culture, we transfected hippocampal neurons with epitope-tagged PSD-95, which accumulates in spines. Control neurons at $\sim 20$ DIV (transfected with PSD-95 at 7 DIV) showed spines (defined in Materials and Methods) at a density of $6.07 \pm 1.83$ (mean $\pm \mathrm{SD}$ ) spines per $10 \mu \mathrm{m}$ dendrite length (Fig. $4 A$ ), consistent with previous measurements in dissociated hippocampal cultures (Sala et al., 2001). Sister cultures treated for $5 \mathrm{~d}$ from 14 DIV with inhibitors of sphingolipid and cholesterol synthesis showed striking changes in spine morphology. Spine den- sity was greatly reduced (to $2.36 \pm 0.89$, mean $\pm \mathrm{SD}$; spines per $10 \mu \mathrm{m}$ dendrite; $p<0.0001$; Mann-Whitney $U$ test), and remaining spines were enlarged (Fig. $4 B$, arrowheads), particularly in terms of diameter of spine head (Fig. 4D). With longer treatment with the inhibitors ( $\geq 10 \mathrm{~d}$ ), dendritic spine density decreased further (Fig. 4C), ultimately resulting in a virtual absence of spines on raft-depleted neurons (data not shown). The enlarged spine heads in raft-depleted cells were apposed to the presynaptic marker bassoon (Fig. $4 F$ ), indicating that they received presynaptic innervation. The presynaptic terminals in raft-depleted culture cells were efficiently labeled by uptake of FM 1-43 dye, indicating that presynaptic function was not grossly impaired (Fig. $4 \mathrm{H}$ ).

As an alternate method to deplete membrane cholesterol, we used $\mathrm{m} \beta \mathrm{CD}$, a chelator of sterols with high affinity for cholesterol. Incubation with $\mathrm{m} \beta \mathrm{CD}$ rapidly extracts cholesterol from cell membranes, allowing one to study the acute effects of raft depletion (Christian et al., 1997). Control neurons showed dendrites with numerous spines, as visualized by DiI labeling (Fig. $5 A$ ). However, neurons treated with $5 \mathrm{~mm} \mathrm{~m} \beta C D$ for $20 \mathrm{~min}$ exhibited complete loss of spines associated with beading of dendrites (Fig. 5B). These morphological changes are reminiscent of neurons exposed to excitotoxic concentrations of NMDA or glutamate (Hasbani et al., 2001). However, the dendritic varicosities and loss of spines induced by $\mathrm{m} \beta \mathrm{CD}$ treatment were not prevented by TTX $(100 \mu \mathrm{M})$ or AP-5 $(100 \mu \mathrm{M})$ plus CNQX $(30 \mu \mathrm{M})$ (Fig. 5C). Thus, the morphological effect of acute cholesterol depletion by $\mathrm{m} \beta \mathrm{CD}$ is not secondary to activation of ionotropic glutamate receptors and excitotoxicity.

NMDA-induced spine loss and dendritic varicosity formation is accompanied by a breakdown of F-actin in spines (Halpain et al., 1998). To assess whether F-actin depolymerization is required for the morphological effect of $\mathrm{m} \beta \mathrm{CD}$, we preincubated neurons for $1 \mathrm{hr}$ with $2 \mu \mathrm{M}$ jasplakinolide, a membrane-permeant F-actin- 


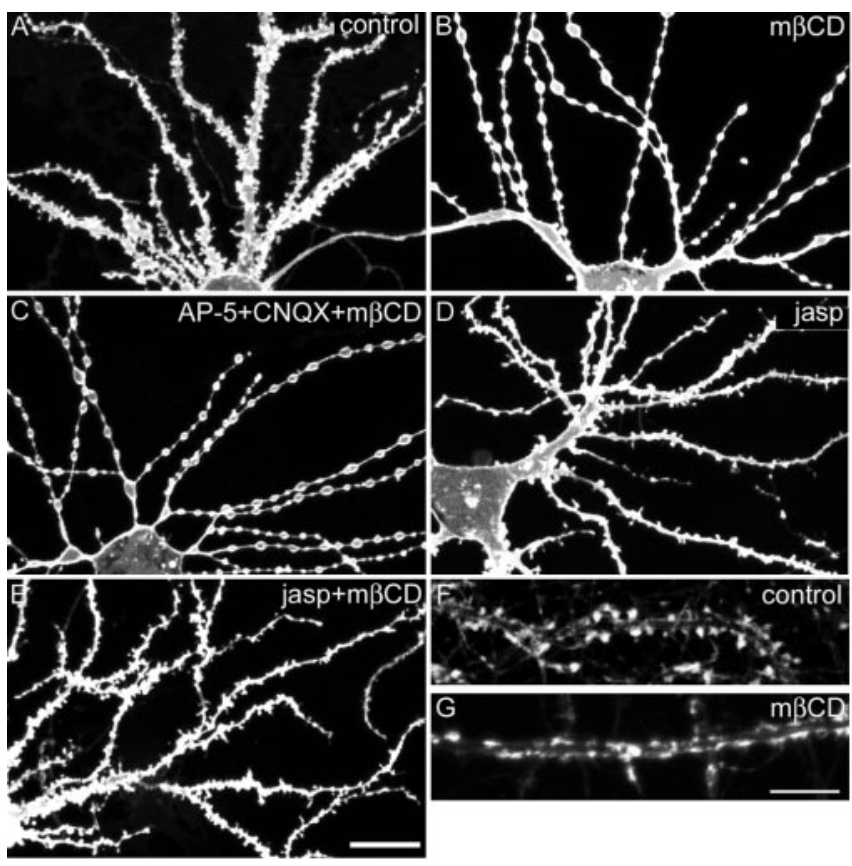

Figure 5. Effects of acute cholesterol extraction by methyl- $\beta$-cyclodextrin on spines. $A-E$, Dendritic morphology was visualized by Dil staining of hippocampal neurons at 25 DIV: untreated control neuron $(A)$, neuron extracted with $5 \mathrm{~mm} \mathrm{~m} \beta C D(B)$, neuron extracted with $5 \mathrm{~mm}$ $\mathrm{m} \beta C D$ in the presence of $100 \mu \mathrm{m} \mathrm{AP}-5$ and $30 \mu \mathrm{M} C \mathrm{NQX}(C)$, neuron treated with $2 \mu \mathrm{m}$ jasplakinolide (jasp; $D, E$ ), or neuron treated with $2 \mu \mathrm{m}$ jasplakinolide followed by $\mathrm{m} \beta C D(E) . F, G$, Dendrite of control neuron at 25 DIV $(F)$ or an $\mathrm{m} \beta C D$-extracted neuron $(G)$ labeled for $F$-actin with Oregon Green-phalloidin. Scale bars: $A-D, 20 \mu \mathrm{m} ; F, G, 10 \mu \mathrm{m}$

stabilizing drug. Jasplakinolide alone did not alter the shape of dendrites or spines (Fig. 5D). However, jasplakinolide blocked the spine loss and dendritic beading induced by $\mathrm{m} \beta \mathrm{CD}$ (Fig. $5 E$ ); thus, the morphological changes after acute cholesterol depletion depend on actin rearrangement. In keeping with this idea, we noted a redistribution of $\mathrm{F}$-actin in $\mathrm{m} \beta \mathrm{CD}$-treated neurons. In control hippocampal neurons, Oregon Green-tagged phalloidin strongly labeled F-actin in dendritic spines (Fig. $5 F$ ), whereas in $\mathrm{m} \beta \mathrm{CD}$-treated neurons, phalloidin labeled flat elongated patches along the dendritic shaft (Fig. 5G). Together, the above findings suggest that acute cholesterol depletion by $\mathrm{m} \beta \mathrm{CD}$ leads to spine loss, secondary to effects on the actin cytoskeleton and independent of synaptic activity.

\section{Lipid raft association of surface AMPA receptors}

Our biochemical data (Fig. 1) indicate that a subpopulation of AMPA receptors is associated with lipid rafts. Does the raftassociated pool of AMPA receptors reside in the plasma membrane? To test this possibility, we labeled live hippocampal neurons with an antibody against an extracellular domain of GluR1, followed by detergent extraction in $0.5 \%$ Triton X-100 at $4^{\circ} \mathrm{C}$ before fixation. In control neurons, AMPA receptors were distributed in clusters along the dendrites and on spines (Fig. 6A1), with additional diffuse GluR1 labeling between the clusters (Fig. $6 A 2)$. In Triton X-100-treated cultures, most of the diffuse and some of the clustered staining had disappeared (Fig. 6B). However, numerous clusters were still detectable after the treatment, indicating that a subset of surface AMPA receptors was resistant to extraction by cold Triton X-100. The detergent-resistance of the AMPA receptors could be attributable to their association with lipid rafts or the cytoskeleton. To distinguish between the two possibilities, we extracted neurons in $0.5 \%$ Triton X-100 at
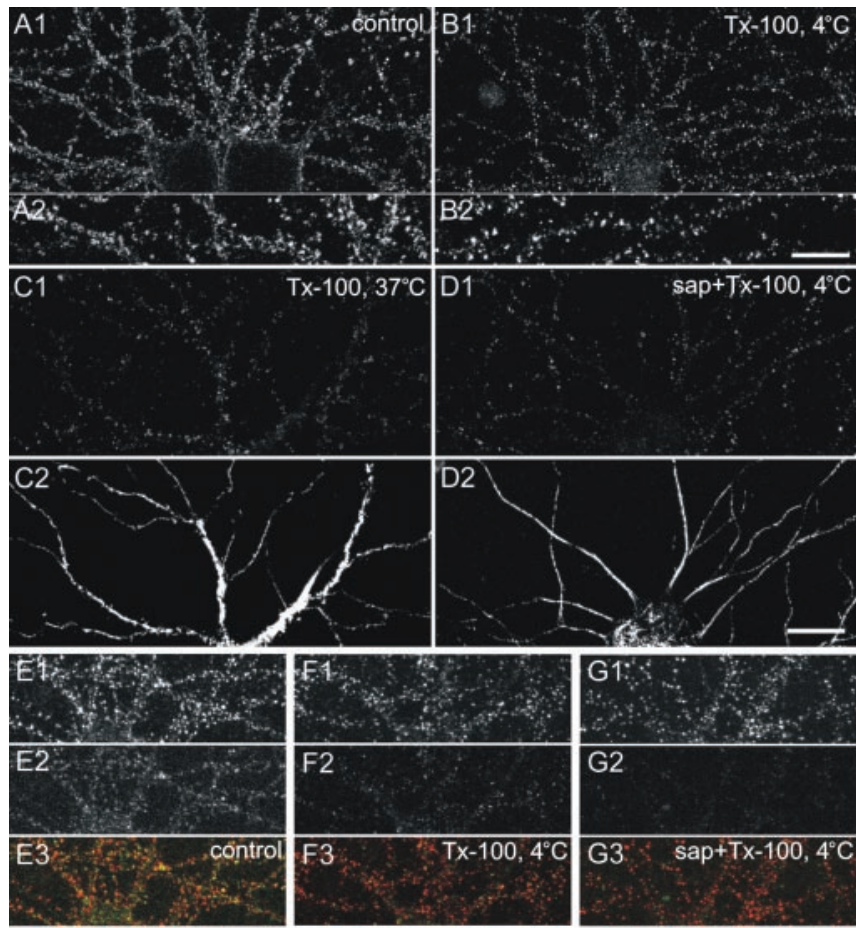

Figure 6. Raft association of surface AMPA receptors. $A 1, A 2$, Surface AMPA receptors on hippocampal neurons at 19 DIV revealed by labeling live neurons with antibodies against $e x-$ tracellular domain of GluR1. B1, B2, Surface AMPA receptors after extraction of neurons with $0.5 \%$ Triton $\mathrm{X}-100(\mathrm{Tx}-100)$ at $4^{\circ} \mathrm{C}$. ( $A 2$ and $B 2$ are higher magnifications of dendrites than $A 1$ and $B 1$.) $C 1$, Surface AMPA receptors after extraction with $0.5 \%$ Triton $X-100$ at $37^{\circ} \mathrm{C} . D 1$, Surface AMPA receptors after extraction with $0.5 \%$ saponin (sap), followed by $0.5 \%$ Triton $X-100$ at $4^{\circ} \mathrm{C}$. ( $(2$ and $D 2$ show the same neuron as in $C 1$ and $D 1$, respectively, double-labeled with MAP2 antibody to indicate dendrites). E, Double-labeling of PSD-95 (E1) and surface AMPA receptors (E2) in untreated control neurons. $F$, Double-labeling of PSD-95 (F1) and surface AMPA receptors (F2) in neurons extracted with $0.5 \%$ Triton $X-100$ at $4^{\circ} \mathrm{C}$. G, Double-labeling of PSD-95 (G1) and surface AMPA receptors (G2) in neurons extracted with $0.5 \%$ saponin (sap), followed by $0.5 \%$ Triton $X-100$ at $4^{\circ} \mathrm{C}$. Bottom panels $(E 3, F 3, G 3)$ show in color the merged image of PSD-95 (red) and AMPA-receptor surface staining (green). Scale bars: $A 1, B 1, C-G, 20$ $\mu \mathrm{m} ; A 2, B 2,5 \mu \mathrm{m}$.

$37^{\circ} \mathrm{C}$, which solubilizes lipid rafts (Brown and London, 1998) but leaves the cytoskeleton intact (Letourneau, 1983; Gillespie et al., 1989). In fact, $37^{\circ} \mathrm{C}$ Triton $\mathrm{X}-100$ extraction removed the vast majority of surface AMPA receptor staining (Fig. 6C1). Secondly, we pretreated cultures with $0.5 \%$ saponin, which extracts cholesterol from membranes and disrupts lipid rafts (Schroeder et al., 1998). In saponin-pretreated neurons, almost all of the surface AMPA receptors were extractable in Triton X-100 at $4^{\circ} \mathrm{C}$ (Fig. $6 D)$. To show the specificity of these effects for AMPA receptors, we double-labeled neurons for surface AMPA receptors and PSD-95. In unextracted control neurons, PSD-95 (Fig. 6E1) and surface AMPA receptors (Fig. 6E2) appeared in numerous clusters along dendrites that showed a high degree of colocalization (Fig. 6E3). However, extraction in cold Triton X-100 removed a substantial amount of surface AMPA receptor staining (Fig. 6F2), but the PSD-95 labeling appeared unchanged (Fig. 6F1). Similarly, the PSD-95 staining pattern was not altered by the treatment of neurons with saponin followed by Triton X-100 extraction (Fig. 6G1), whereas surface AMPA receptors were almost completely extracted under these conditions (Fig. 6G2). Together, these data argue that a subpopulation of AMPA receptors in the plasma membrane of hippocampal neurons is associated with lipid rafts. 

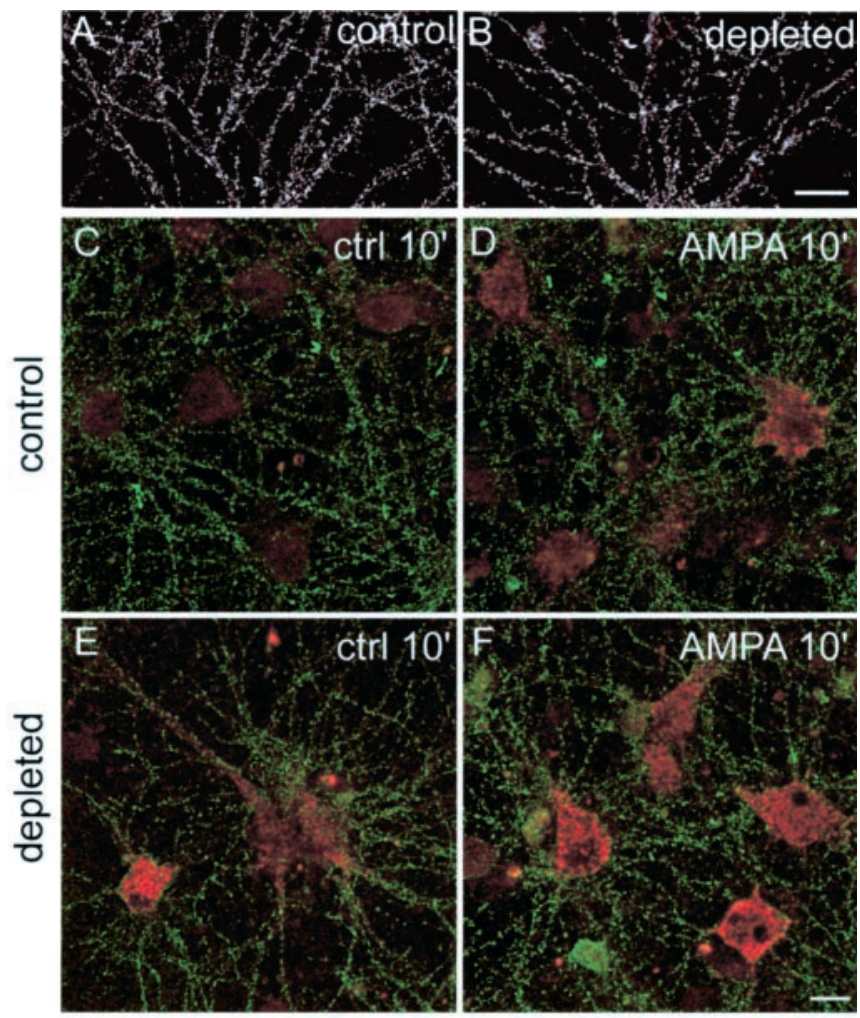

G

GluR1 internalization

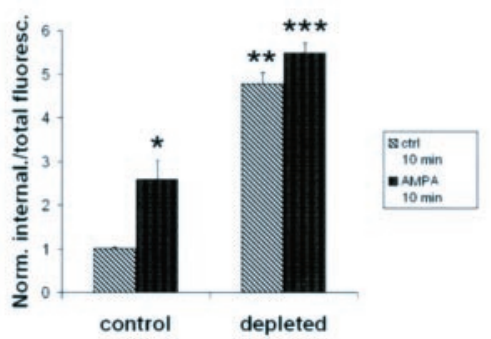

Figure 7. AMPA receptor internalization in raft-depleted neurons. $A, B$, Surface AMPA receptors (GluR1) on control $(A)$ and raft-depleted $(B)$ hippocampal neurons. $(-F$, Antibodyfeeding assay showing remaining surface AMPA receptors (green) and internalized AMPA receptors (red) at $10 \mathrm{~min}$ after surface labeling of AMPA receptors on live neurons. $C, D$, Non-raftdepleted neurons, untreated $(C)$ or stimulated with $100 \mu \mathrm{M}$ AMPA in the presence of $100 \mu \mathrm{M}$ AP-5 (D).E, F, Raft-depleted neurons, untreated (E) or stimulated with $100 \mu \mathrm{m}$ AMPA and 100 $\mu \mathrm{m}$ AP-5 $(F) . G$, Quantitation of results illustrated in $(-F$. Histograms show mean $\pm \mathrm{SEM} ; n=$ 6 microscope fields for each condition. ${ }^{*} p=0.035$ and ${ }^{* *} p=0.0012$ compared with control (ctrl) $10^{\prime} ;{ }^{* * *} p=0.0012$ compared with control/AMPA 10' (Mann-Whitney $U$ test). Scale bars: $A, B, 20 \mu \mathrm{m} ; C-F, 10 \mu \mathrm{m}$.

\section{AMPA receptor endocytosis and lipid rafts}

AMPA receptors cycle in and out of the postsynaptic membrane via constitutive and regulated exocytic and endocytic pathways (Carroll et al., 2001; Sheng and Lee, 2001). Because lipid rafts are implicated in endocytic trafficking, we asked whether the dynamics of AMPA receptor internalization might be dependent on lipid rafts. Cholesterol/sphingolipid depletion did not change the level of AMPA receptors on the surface of neurons (Fig. $7 A, B$ ). The surface-staining intensity of GluR1 on dendrites at steady state was not significantly different between control and raftdepleted neurons (control, $0.98 \pm 0.046$ arbitrary units; mean \pm SEM; raft-depleted, $1.24 \pm 0.1 ; p=0.081$; Student's $t$ test).

Using an "antibody feeding" assay (Lin et al., 2000), we studied basal and AMPA-stimulated internalization of AMPA recep- tors in control versus raft-depleted neurons. Constitutive endocytosis of AMPA receptors was readily detected in untreated cells, as reported previously (Lin et al., 2000) (Fig. 7C). In control (nonraft-depleted) neurons, we measured a basal internalization of GluR1 in $10 \mathrm{~min}$ (Fig. $7 C$ ) that was stimulated $\sim 2.5$-fold by $100 \mu \mathrm{M}$ AMPA (Fig. $7 D, G$ ). In cholesterol/sphingolipid-depleted cultures, basal internalization of AMPA receptors was strikingly increased. In the absence of AMPA stimulation, the amount of internalized GluR1 at $10 \mathrm{~min}$ in raft-depleted neurons (Fig. 7E) was even greater than in control neurons stimulated with AMPA (Fig. 7D, quantified in $G$ ). AMPA treatment slightly increased the internalization of AMPA receptors in raft-depleted cells, but the difference was not statistically significant (Fig. $7 F, G$ ). The relative lack of AMPA response may be attributable to the high basal rate of receptor internalization in raft-depleted neurons.

\section{Discussion}

\section{Postsynaptic lipid rafts}

In this study, we characterized the lipid raft association of a panel of glutamate receptors and their associated proteins. In agreement with previous reports (Perez and Bredt, 1998; Bruckner et al., 1999; Suzuki et al., 2001), we found that PSD-95, GRIP, and AMPA receptors are present in lipid raft fractions isolated from rat brain. The palmitoylation of PSD-95 and GRIP (Topinka and Bredt, 1998; Yamazaki et al., 2001) could mediate the lipid raft association of these glutamate receptor-binding proteins. In turn, the binding of the C termini of GluR2/3 subunits to GRIP could explain the association of AMPA receptors with rafts. Consistent with such a notion, ephrinB1 depends on its $\mathrm{C}$ terminus for incorporation into lipid rafts (Bruckner et al., 1999). Interestingly, we found that the PSD-95 family protein SAP97 showed no affinity for rafts, correlating with its lack of palmitoylation (Craven et al., 1999). Because it binds robustly to AMPA receptors through the GluR1 subunit (Leonard et al., 1998), SAP97 is presumably associated with a nonraft pool of AMPA receptors. These nonraft AMPA receptors could reside in intracellular compartments, where SAP97 binding to AMPA receptors is reported to primarily occur (Sans et al., 2001).

We detected robust amounts of NMDA receptors in DRMs from the brain, in contrast to a previous study (Suzuki et al., 2001). The presence of NMDA receptors in rafts is in keeping with their binding to PSD-95, which is also associated with rafts. Other neurotransmitter receptors have been found to be associated with lipid rafts, on the basis of "floating DRM" criteria (Becher et al., 2001; Bruses et al., 2001).

Previously, lipid rafts had been characterized in axons, where they are enriched for GPI-anchored proteins such as Thy-1, transient axonal glycoprotein-1, and F3/F11 (Faivre-Sarrailh and Rougon, 1993; Ledesma et al., 1998, 1999). However, it is becoming clear that lipid rafts comprise a variety of microdomains with different lipid and protein compositions, and presumably different functions. We revealed heterogeneity of DRMs in the brain by modifying the density-gradient conditions. In particular, we could distinguish Thy-1 versus caveolin-enriched low-density DRMs (Fig. $1 B$ ). PSD-95, NMDA receptors, and AMPA receptors showed a DRM flotation pattern similar to each other and caveolin but not Thy-1, supporting the idea that these three postsynaptic proteins exist in a similar type of raft (although not necessarily in the same raft microdomain). Because Thy- 1 is concentrated on axons, whereas the postsynaptic proteins are confined to soma and dendrites, it is conceivable that the two types of DRMs represent distinct classes of lipid raft existing in different compartments of the neuron. In this context, it is noteworthy 
that the fractionation pattern of GRIP resembles Thy- 1 as well as glutamate receptors. This wider distribution may relate to the fact that GRIP is present in axons as well as dendrites (Wyszynski et al., 1999).

\section{Normal density of synapses and spines depends on lipid rafts}

Acute extraction of cholesterol (e.g., with $\mathrm{m} \beta \mathrm{CD}$ ) seriously affects the viability of hippocampal neurons (Koudinov and Koudinova, 2001). We therefore studied lipid raft function in neurons by chronically interfering with the metabolic synthesis of cholesterol and sphingolipids. In our hands, such treatment does not cause obvious cell death or morphological correlates of ill health in cultured hippocampal neurons over a period of 2 weeks.

Because various glutamate receptors and postsynaptic scaffold proteins are associated with rafts, we focused on the postsynaptic specialization in this study. In this respect, two major effects were seen in raft-depleted neurons: a reduced density of synapses and spines, and an enlargement of the remaining synapses and spines. With very prolonged treatment, neurons lost their spines and synapses almost completely. Because excitatory synapses in hippocampal neurons are usually located on spines, and synapse maturation correlates temporally with spine stabilization (Okabe et al., 2001), it seems likely that spine loss and synapse loss are closely linked. Indeed, after $5 \mathrm{~d}$ of cholesterol/sphingolipid depletion, there was a quantitative correlation between the reduced density of PSD-95 clusters ( $\sim 37 \%$ of control) and spines $(\sim 39 \%)$. We cannot tell whether the loss of spines is secondary to synapse loss or vice versa. Because low levels of synaptic activity are required to maintain spines in hippocampal organotypic cultures (McKinney et al., 1999), it is possible that spine density decreases as a consequence of loss of synapses. In the case of inhibitory synapses, which are not formed on dendritic spines but are equally affected by cholesterol/sphingolipid depletion, the attrition of synapses cannot be blamed on spine loss.

Because synapses and spines show dynamic turnover, the gradual loss of these structures could reflect a role for lipid rafts in either the formation or stability of spines and synapses. How might raft microdomains be important for these processes? One simple explanation is that rafts are primarily required for the synaptic targeting of proteins essential for the formation and/or maintenance of synapses. Under conditions of cholesterol/sphingolipid depletion, the trafficking of raft-associated proteins to synapses might be disrupted, resulting in impaired construction of new synapses and/or decay of existing synapses. However, concurrent with the disappearance of synapses, we observed an increased accumulation of several raft-associated proteins (such as NMDA receptors, and PSD-95) at the remaining synapses, arguing against a gross disturbance of protein targeting to synapses in raft-depleted neurons.

The actin cytoskeleton supports the spine and is necessary for synapse integrity and plasticity (for review, see Matus, 2000). Lipid rafts are intimately linked to F-actin and its local regulation (Foger et al., 2001; Itoh et al., 2002). Thus cholesterol/sphingolipid depletion could lead to weakened interaction of F-actin with the spine membrane, destabilization of spine actin, and ultimately collapse of existing spines or impaired formation of new ones. Consistent with a relatively direct effect of raft depletion on the actin cytoskeleton, acute extraction of cholesterol by $\mathrm{m} \beta \mathrm{CD}$ caused an immediate collapse of spines associated with redistribution of F-actin from dendritic spine to dendritic shaft (Fig. 5). A similar disruption of actin-rich membrane protrusions as a result of lipid-raft removal has been shown for microvilli and lamellipodia on fibroblasts and somatic spines on ciliary ganglion neurons (Meivar-Levy et al., 1997; Bruses et al., 2001). Finally, we cannot rule out that lowering the cholesterol and sphingolipid levels in neurons directly affects the fluidity and curvature of the plasma membrane, thereby leading to a collapse of spines.

\section{Lipid rafts and AMPA receptor endocytosis}

The basal internalization of AMPA receptors was increased in raft-depleted neurons, suggesting that cholesterol/sphingolipid microdomains help to stabilize surface AMPA receptors. Consistent with this idea, AMPA receptors are at least in part associated with DRMs on the cell surface. How might lipid rafts stabilize AMPA receptors in the plasma membrane? An indirect effect through the actin cytoskeleton is possible because AMPA receptor internalization is also increased in hippocampal neurons after actin depolymerization (Zhou et al., 2001). Alternatively, raft depletion may disrupt the subcellular targeting of a protein such as palmitoylated GRIP, impairing the interaction of GRIP with GluR2/3 and leading to destabilization of AMPA receptors at the postsynaptic membrane. Whatever the precise mechanism, the selective partitioning of surface AMPA receptors in and out of lipid rafts may provide a means to regulate AMPA receptor endocytosis and segregate AMPA receptors from other synaptic membrane proteins that are not destined for internalization.

\section{Cholesterol, glia, and neurodegeneration}

A recent report (Mauch et al., 2001) identified cholesterol as the glia-derived factor that promotes synapse formation between purified retinal ganglion neurons; however, why cholesterol is needed by neurons to develop mature synapses was not addressed. Based on our findings, in which cholesterol/sphingolipid depletion causes an end result reminiscent of culturing retinalganglion cells in the absence of glia, we propose that the importance of glia-derived cholesterol for synapse development lies in feeding the production of lipid rafts in neurons. Presumably then, cholesterol synthesis in neurons is limiting for synapse formation/maturation. Although glial cells are not abundant in our hippocampal cultures, fumonisin and mevastatin could be acting at least in part on glial cells that are providing cholesterol to neurons.

The delivery of cholesterol from glial cells to neurons seems to be mediated by cholesterol transport protein apolipoprotein $\mathrm{E}$ (apoE) (Mauch et al., 2001). The apoE4 allele is an important risk factor for Alzheimer's disease (Strittmatter et al., 1993; Locke et al., 1995), as are elevated serum cholesterol levels (Notkola et al., 1998; Jick et al., 2000). Moreover, the cleavage of amyloidprecursor protein to $\mathrm{A} \beta$ is modulated by levels of membrane cholesterol (Simons et al., 1998; Refolo et al., 2000). Thus, disordered cholesterol metabolism is implicated in the pathogenesis of Alzheimer's disease. Here, we have provided evidence that a major function of cholesterol in neurons is to support lipid rafts, and that depletion of cholesterol/sphingolipid leads to a gradual loss of synapses and spines, which is a central feature of neurodegenerative diseases. Our findings thus offer a possible cell-biological basis for the connection between cholesterol metabolism and the degeneration of synapses seen in human disease.

\section{References}

Becher A, White JH, McIlhinney RA (2001) The gamma-aminobutyric acid receptor $\mathrm{B}$, but not the metabotropic glutamate receptor type-1, associates with lipid rafts in the rat cerebellum. J Neurochem 79:787-795.

Brown DA, London E (1998) Structure and origin of ordered lipid domains in biological membranes. J Membr Biol 164:103-114.

Brown DA, Rose JK (1992) Sorting of GPI-anchored proteins to glycolipid- 
enriched membrane subdomains during transport to the apical cell surface. Cell 68:533-544.

Bruckner K, Pablo Labrador J, Scheiffele P, Herb A, Seeburg PH, Klein R (1999) EphrinB ligands recruit GRIP family PDZ adaptor proteins into raft membrane microdomains. Neuron 22:511-524.

Bruses JL, Chauvet N, Rutishauser U (2001) Membrane lipid rafts are necessary for the maintenance of the $\alpha 7$ nicotinic acetylcholine receptor in somatic spines of ciliary neurons. J Neurosci 21:504-512.

Caroni P (2001) New EMBO members' review: actin cytoskeleton regulation through modulation of $\mathrm{PI}(4,5) \mathrm{P}(2)$ rafts. EMBO J 20:4332-4336.

Carroll RC, Beattie EC, von Zastrow M, Malenka RC (2001) Role of AMPA receptor endocytosis in synaptic plasticity. Nat Rev Neurosci 2:315-324.

Christian AE, Haynes MP, Phillips MC, Rothblat GH (1997) Use of cyclodextrins for manipulating cellular cholesterol content. J Lipid Res 38:2264-2272.

Craven SE, El-Husseini AE, Bredt DS (1999) Synaptic targeting of the postsynaptic density protein PSD-95 mediated by lipid and protein motifs. Neuron 22:497-509.

Dotti CG, Parton RG, Simons K (1991) Polarized sorting of glypiated proteins in hippocampal neurons. Nature 349:158-161.

Faivre-Sarrailh C, Rougon G (1993) Are the glypiated adhesion molecules preferentially targeted to the axonal compartment? Mol Neurobiol 7:49-60.

Foger N, Marhaba R, Zoller M (2001) Involvement of CD44 in cytoskeleton rearrangement and raft reorganization in T cells. J Cell Sci 114:1169-1178.

Gillespie CS, Wilson R, Davidson A, Brophy PJ (1989) Characterization of a cytoskeletal matrix associated with myelin from rat brain. Biochem J 260:689-696.

Gomez-Mouton C, Abad JL, Mira E, Lacalle RA, Gallardo E, JimenezBaranda S, Illa I, Bernad A, Manes S, Martinez AC (2001) Segregation of leading-edge and uropod components into specific lipid rafts during $\mathrm{T}$ cell polarization. Proc Natl Acad Sci USA 98:9642-9647.

Halpain S, Hipolito A, Saffer L (1998) Regulation of F-actin stability in dendritic spines by glutamate receptors and calcineurin. J Neurosci 18:9835-9844.

Hasbani MJ, Schlief ML, Fisher DA, Goldberg MP (2001) Dendritic spines lost during glutamate receptor activation reemerge at original sites of synaptic contact. J Neurosci 21:2393-2403.

Hering H, Sheng M (2001) Dendritic spines: structure, dynamics and regulation. Nat Rev Neurosci 2:880-888.

Itoh K, Sakakibara M, Yamasaki S, Takeuchi A, Arase H, Miyazaki M, Nakajima N, Okada M, Saito T (2002) Cutting edge: negative regulation of immune synapse formation by anchoring lipid raft to cytoskeleton through Cbp-EBP50-ERM assembly. J Immunol 168:541-544.

Jick H, Zornberg GL, Jick SS, Seshadri S, Drachman DA (2000) Statins and the risk of dementia. Lancet 356:1627-1631.

Kim E, Sheng M (1996) Differential K+ channel clustering activity of PSD-95 and SAP97, two related membrane-associated putative guanylate kinases. Neuropharmacology 35:993-1000.

Kim E, Niethammer M, Rothschild A, Jan YN, Sheng M (1995) Clustering of Shaker-type $\mathrm{K}+$ channels by interaction with a family of membraneassociated guanylate kinases. Nature 378:85-88.

Koudinov AR, Koudinova NV (2001) Essential role for cholesterol in synaptic plasticity and neuronal degeneration. FASEB J 15:1858-1860.

Ledesma MD, Simons K, Dotti CG (1998) Neuronal polarity: essential role of protein-lipid complexes in axonal sorting. Proc Natl Acad Sci USA 95:3966-3971.

Ledesma MD, Brugger B, Bunning C, Wieland FT, Dotti CG (1999) Maturation of the axonal plasma membrane requires upregulation of sphingomyelin synthesis and formation of protein-lipid complexes. EMBO J 18:1761-1771.

Leonard AS, Davare MA, Horne MC, Garner CC, Hell JW (1998) SAP97 is associated with the alpha-amino-3-hydroxy-5-methylisoxazole-4propionic acid receptor GluR1 subunit. J Biol Chem 273:19518-19524.

Letourneau PC (1983) Differences in the organization of actin in the growth cones compared with the neurites of cultured neurons from chick embryos. J Cell Biol 97:963-973.

Lin JW, Ju W, Foster K, Lee SH, Ahmadian G, Wyszynski M, Wang YT, Sheng M (2000) Distinct molecular mechanisms and divergent endocytotic pathways of AMPA receptor internalization. Nat Neurosci 3:1282-1290.

Locke PA, Conneally PM, Tanzi RE, Gusella JF, Haines JL (1995) Apolipoprotein $\mathrm{E} 4$ allele and Alzheimer disease: examination of allelic associa- tion and effect on age at onset in both early- and late-onset cases. Genet Epidemiol 12:83-92.

Madore N, Smith KL, Graham CH, Jen A, Brady K, Hall S, Morris R (1999) Functionally different GPI proteins are organized in different domains on the neuronal surface. EMBO J 18:6917-6926.

Manes S, Mira E, Gomez-Mouton C, Lacalle RA, Keller P, Labrador JP, Martinez AC (1999) Membrane raft microdomains mediate front-rear polarity in migrating cells. EMBO J 18:6211-6220.

Matus A (2000) Actin-based plasticity in dendritic spines. Science 290:754-758.

Mauch DH, Nagler K, Schumacher S, Goritz C, Muller EC, Otto A, Pfrieger FW (2001) CNS synaptogenesis promoted by glia-derived cholesterol. Science 294:1354-1357.

McKinney RA, Capogna M, Durr R, Gahwiler BH, Thompson SM (1999) Miniature synaptic events maintain dendritic spines via AMPA receptor activation. Nat Neurosci 2:44-49.

Meivar-Levy I, Sabanay H, Bershadsky AD, Futerman AH (1997) The role of sphingolipids in the maintenance of fibroblast morphology. The inhibition of protrusional activity, cell spreading, and cytokinesis induced by fumonisin B1 can be reversed by ganglioside GM3. J Biol Chem 272:1558-1564.

Mukherjee S, Soe TT, Maxfield FR (1999) Endocytic sorting of lipid analogues differing solely in the chemistry of their hydrophobic tails. J Cell Biol 144:1271-1284.

Naisbitt S, Kim E, Tu JC, Xiao B, Sala C, Valtschanoff J, Weinberg RJ, Worley PF, Sheng M (1999) Shank, a novel family of postsynaptic density proteins that binds to the NMDA receptor/PSD-95/GKAP complex and cortactin. Neuron 23:569-582.

Nichols BJ, Lippincott-Schwartz J (2001) Endocytosis without clathrin coats. Trends Cell Biol 11:406-412.

Notkola IL, Sulkava R, Pekkanen J, Erkinjuntti T, Ehnholm C, Kivinen P, Tuomilehto J, Nissinen A (1998) Serum total cholesterol, apolipoprotein E epsilon 4 allele, and Alzheimer's disease. Neuroepidemiology 17:14-20.

Okabe S, Miwa A, Okado H (2001) Spine formation and correlated assembly of presynaptic and postsynaptic molecules. J Neurosci 21:6105-6114.

Perez AS, Bredt DS (1998) The N-terminal PDZ-containing region of postsynaptic density-95 mediates association with caveolar-like lipid domains. Neurosci Lett 258:121-123.

Refolo LM, Malester B, LaFrancois J, Bryant-Thomas T, Wang R, Tint GS, Sambamurti K, Duff K, Pappolla MA (2000) Hypercholesterolemia accelerates the Alzheimer's amyloid pathology in a transgenic mouse model. Neurobiol Dis 7:321-331.

Roper K, Corbeil D, Huttner WB (2000) Retention of prominin in microvilli reveals distinct cholesterol-based lipid micro-domains in the apical plasma membrane. Nat Cell Biol 2:582-592.

Sala C, Rudolph-Correia S, Sheng M (2000) Developmentally regulated NMDA receptor-dependent dephosphorylation of cAMP response element-binding protein (CREB) in hippocampal neurons. J Neurosci 20:3529-3536.

Sala C, Piech V, Wilson NR, Passafaro M, Liu G, Sheng M (2001) Regulation of dendritic spine morphology and synaptic function by Shank and Homer. Neuron 31:115-130.

Sans N, Racca C, Petralia RS, Wang YX, McCallum J, Wenthold RJ (2001) Synapse-associated protein 97 selectively associates with a subset of AMPA receptors early in their biosynthetic pathway. J Neurosci 21:7506-7516.

Schroeder RJ, Ahmed SN, Zhu Y, London E, Brown DA (1998) Cholesterol and sphingolipid enhance the Triton X-100 insolubility of glycosylphosphatidylinositol-anchored proteins by promoting the formation of detergentinsoluble ordered membrane domains. J Biol Chem 273:1150-1157.

Seveau S, Eddy RJ, Maxfield FR, Pierini LM (2001) Cytoskeleton-dependent membrane domain segregation during neutrophil polarization. Mol Biol Cell 12:3550-3562.

Sheng M, Lee SH (2001) AMPA receptor trafficking and the control of synaptic transmission. Cell 105:825-828.

Simons K, Ikonen E (1997) Functional rafts in cell membranes. Nature 387:569-572.

Simons K, Toomre D (2000) Lipid rafts and signal transduction. Nat Rev Mol Cell Biol 1:31-39.

Simons M, Keller P, De Strooper B, Beyreuther K, Dotti CG, Simons K 
(1998) Cholesterol depletion inhibits the generation of beta-amyloid in hippocampal neurons. Proc Natl Acad Sci USA 95:6460-6464.

Strittmatter WJ, Saunders AM, Schmechel D, Pericak-Vance M, Enghild J, Salvesen GS, Roses AD (1993) Apolipoprotein E: high-avidity binding to beta-amyloid and increased frequency of type 4 allele in late-onset familial Alzheimer disease. Proc Natl Acad Sci USA 90:1977-1981.

Suzuki T, Ito J, Takagi H, Saitoh F, Nawa H, Shimizu H (2001) Biochemical evidence for localization of AMPA-type glutamate receptor subunits in the dendritic raft. Brain Res Mol Brain Res 89:20-28.

Topinka JR, Bredt DS (1998) N-terminal palmitoylation of PSD-95 regulates association with cell membranes and interaction with $\mathrm{K}+$ channel Kv1.4. Neuron 20:125-134.

Wyszynski M, Kim E, Yang FC, Sheng M (1998) Biochemical and immuno- cytochemical characterization of GRIP, a putative AMPA receptor anchoring protein, in rat brain. Neuropharmacology 37:1335-1344.

Wyszynski M, Valtschanoff JG, Naisbitt S, Dunah AW, Kim E, Standaert DG, Weinberg R, Sheng M (1999) Association of AMPA receptors with a subset of glutamate receptor-interacting protein in vivo. J Neurosci 19:6528-6537.

Yamazaki M, Fukaya M, Abe M, Ikeno K, Kakizaki T, Watanabe M, Sakimura K (2001) Differential palmitoylation of two mouse glutamate receptor interacting protein 1 forms with different $\mathrm{N}$-terminal sequences. Neurosci Lett 304:81-84.

Zhou Q, Xiao M, Nicoll RA (2001) Contribution of cytoskeleton to the internalization of AMPA receptors. Proc Natl Acad Sci USA 98:12611266. 